\title{
English as an International Language:
}

\section{A Functional Role in South Korea}

\author{
Simon James Nicholson \\ Assistant Professor, Hankuk University of Foreign Studies \\ 89 Wangsan-ri, Mohyeon-myeon, Choin-gu, Yongin-si, Gyeonggi-do, South Korea \\ Tel: +82 1089741948 E-mail: simonjamesnicholson@gmail.com
}

Received: February 26, 2015 Accepted: March 7, 2015 Published: March 7, 2015

doi:10.5296/jsel.v3i1.7201ＵRL: http://dx.doi.org/10.5296/jsel.v3i1.7201

\begin{abstract}
In South Korea English as an International Language (EIL) is neither neutral, imperialistic nor democratic but rather functional and pragmatic and inherently linked to the country's development. It is not a language being used internally for communicative purposes. Rather, it is an additional linguistic skill being learnt for the purposes of international business communication and academic advancement both contributing to South Korea's rising presence in the international arena. This paper examines the role of English as an International Language in South Korea and the roles played by language in society and culture. It looks at the implications that this has for teaching English in South Korea and the need to focus on interpretability to expose students to as many varieties of English as possible to prepare for the linguistic diversity that they are likely to encounter in their own locale.

Keywords: English International Language, Culture, Society, Concentric Circles, Neutral, Imperialist, Democratic, Maintenance, Development
\end{abstract}




\section{Introduction}

The role that English plays in the world today carries with it many contradictions as both the language of opportunity and oppression, and the effects that it has on local identities and societies as they strive to be included in an increasingly globalized world has yet to be fully understood. What is clear is that English is the most common language in the world with a projected number of "over 3 billion speakers by 2050" (British Council 2004; cited in Wardhaugh, 2006: 379). Additionally, Crystal asserts:

English is now spoken by more people (as a first, second, or foreign language) than any other language and is recognized by more countries as a desirable lingua franca than any other language. (2001: 54)

This has not only led to an increase in the number of its speakers but also a widespread geographical switch in the location of those who speak it, which in turn has led to the development of World English varieties. Yano observes that English:

...has transformed itself into varieties of Englishes and in fact communication between non-native speakers of English is now far greater in frequency, amount, and significance as well as the number of speakers today. (Crystal 1997, Graddol 1997; cited in Yano 2003: 78)

The implications of this are not only far reaching for the role of English as an International Language (EIL) in the world, but are of considerable importance to English as a Foreign Language (EFL) professionals.

To further examine these issues, this paper will first explore the neutral, democratic and imperialist opinions regarding the role of EIL in its current global context. The author will then identify the function of language in relationship to society before considering the specific position of EIL in regards to the maintenance and development of Korean society. The paper will then propose that in South Korea EIL is neither neutral, imperialistic nor democratic but rather functional and pragmatic and inherently linked to the country's development. The writer will then discuss the implications that this has for teaching English in South Korea.

\section{English as an International Language}

The term EIL was first proposed by Smith (1976) and is defined as a language that is used between members who come from different 'linguacultures'. It is a language used for international communication in contexts "between speakers coming from different cultural and national backgrounds" (Sharifan, 2009: 3). It therefore plays a specific function in any non-English speaking country: to facilitate communication in international contexts between speakers who do not share the same common language. However, the role that English plays in any given society or culture varies considerably. To better understand these differences it is helpful to make reference to Kachru's concentric circles of English, as they will be referred to throughout this paper. 


\section{Concentric Circles of English}

Braj Kachru (1982) distinguishes the different ways that countries use English by placing them into the following three concentric circles:

- Inner-Circle countries, where English is used as the primary language, such as in the United Kingdom, the United States, Australia and Canada.

- Outer-Circle countries, where the users are multilingual and its use is as a second language, such as India and Singapore.

- Expanding-Circle countries, the largest circle, where English is learned as a foreign language, such as in China, Japan, Korea and Egypt.

Although a useful distinction regarding how the English language is used in these countries (and one that will be applied throughout the paper), it is somewhat irrelevant to view EIL in this context given that EIL is used between speakers coming from different cultural backgrounds and we are not so much concerned with how the language is used inside countries of any given circle, but with its use between different countries in different circles and between different countries within the same circles as a tool of communication.

\section{The Role of English as an International Language}

The following section will give a brief outline of each of the arguments and counter-arguments prominent in the literature for the role of EIL in the world today.

\subsection{English is Neutral}

World English (Bolton, 2004; Kachru, 1986, 1992) is central to the argument that English is neutral in its role as an international language because by definition it recognizes that EIL users are not centered on any single culture and therefore the language attains a degree of neutrality. McKay states, "the very nature of English has changed in terms of how many of its speakers make use of English and how English relates to culture" (2003: 2). With English now being spoken by more people in the outer and expanding circles than those in the inner circle, the language seems no longer culturally tied to inner circle countries as every speaker of English, regardless of culture, has ownership of the language. As Wardhaugh notes, "since no cultural requirements are tied to the learning of English, you can learn it and use it without having to subscribe to another set of values" (Wardaugh, 1987: 14-15; cited in Holland 2002: 5). This implies that because the language is not occupied by any specific culture it therefore carries a degree of neutrality as "once a language comes to be so widespread it ceases to have a single linguistic superpower" (Patil, 2006: 102).

However, counter to the claim that the acquisition and use of the English language is not bound to any specific culture or political system and therefore neutral are those that subscribe to the Sapir-Whorf hypothesis who believe that "you perceive only what your language allows you, or predisposes you, to perceive" (Wardhaugh, 2006: 224). This hypothesis runs counter to the role of EIL as being neutral and holds that "your language controls your 'world-view.' Speakers of different languages will, therefore, have different world-views" 
(Wardhaugh, 2006: 224). Language therefore influences thought and EIL should not be seen as an exception to this hypothesis as even in a bilingual setting it has the effect of altering the thought process of an individual.

I do not support the argument that EIL is totally neutral as no language can be truly neutral. Whether or not a language is bound to any single culture is however a different matter.

\subsection{English is Imperialist}

For some (Phillipson, 1992, Muhlhausler, 1996, and Pennycook, 1998) there is a view that English is "a clear expression of political, cultural, and economic imperialism" (Wardhaugh, 2006: 380). While the English language does have a history of being linked to colonialism, oppression, racism and cultural imperialism (Crystal 2003) so to has it been the language of opposition to these exact things (McCrum, 2010). As Widdowson argues:

There is a fundamental contradiction in the idea that the language of itself exerts hegemonic control: namely that if this were the case, you would never be able to challenge such control. (1998: 398)

English might have arrived at its current position of lingua franca through an imperialist past, but this does not mean that its current position in the world is imperialist. However, that EIL threatens minority languages and serves class interests are additional arguments that supporters of the imperialist role hold.

Cook (1988) and Judd (1983) talk about the threat EIL poses to indigenous languages while Muhlhausler (1996) goes as far as to call it a 'killer language'. Day (1985) refers to EIL's influence in local cultures as 'linguistic genocide' while Nettle and Romaine (2000) echo this sentiment by stating that, "as many as 60 percent of all languages are already endangered" (cited in Wardhaugh, 2006: 379). Their argument is that "as national languages of modernization, education, and development they [World Englishes] stifle and eventually kill local languages" (Wardhaugh, 2006: 380).

In support of these claims Pennycook raises the argument that English "is constantly replacing other languages in daily use and school curricula" (2001: 81). However, to counter these claims is the argument that EIL is not a monolingual but rather a bilingual choice, and one that serves as an additional linguistic tool to the mother tongue (Bisong, 1995).

A second issue worth considering is that EIL serves particular class interests and prevents equal access to wealth and education. Pennycook (2001) considers English to have a central role in creating global inequalities. He states:

[W]ith English taking up such an important position in many educational systems around the world, it has become one of the most powerful means of inclusion into or exclusion from further education, employment or social positions. (2001: 81)

While this may be partially true, it is naïve to think that these global inequalities are purely a result of EIL. More likely than not, they are inequalities that were already long in place within the social structure. 


\subsection{English is Democratic}

Contrary to the claim that those who acquire the language are victims of linguistic imperialism (Phillipson, 1992), Kachru states that, "whatever the reasons for the earlier spread of English, we should now consider it a positive development in the twentieth century world context" (1983: 51). EIL helps to open up opportunities both domestically and internationally that might not necessarily exist by providing access to economic, technological and educational possibilities. With an estimated 84 percent of the world's electronic information stored in English (Graddol, 1997: 51) and a 1980 study showing that 85 percent of papers in biology and physics, 73 per cent of medical papers, 69 percent for mathematics and 67 percent of chemistry papers are written in English (Large 1983: 18; cited in Crystal 2003: 111), EIL offers access to much of the world's educational knowledge. Furthermore:

English is the dominant language of the U.S., the UN, the World Bank, the International Monetary Fund, the Organization for Economic Cooperation and Development, many other world policy organizations, and most of the world's big businesses and elites in many countries worldwide. (Phillipson \& Skutnabb-Kangas, 1996: 441)

It is clear that English plays a vital role in the participation of larger political and educational institutions. Thus, there are clear pragmatic reasons for acquiring English through which its users acquire access to education, information, technology and a larger global community.

The democratic nature of EIL is manifested through the opportunities and resources it provides to people that would not necessarily be available without a working knowledge of English. It therefore "continues to provide unprecedented power for mobility and advancement to those native and non-native users who possess it as a linguistic tool" (Kachru, 1986: 14).

\section{The Roles Played by Language in Society and Culture}

The simplest role of language in any society or culture is that of communicating and sharing ideas and information. Likewise, it is also the identity of any society and culture as it sets those who are from outside a particular society apart from those who are not. Language identifies where people are from, therefore one can conclude that language and society are not independent of each other (Wardhaugh, 2006). What then is the relationship between them? Wardhaugh (2006: 10) gives a multifaceted view of this relationship based on the works of various scholars as follows:

1. Society influences the linguistic structure (Bernstein) - the varieties of language that speakers use reflect such matters as their regional, social, or ethnic origin and that particular ways of speaking, choices of words, and even rules for conversing are in fact highly determined by certain social requirements.

2. Linguistic structure influences society (Whorf)

3. Language and society influence each other (Marx) - speech behavior and social behavior are in a state of constant interaction 
4. Society and language do not influence the linguistic phenomena at all (Chomsky)

What is seen is that the relationship between language and society is a complex network of influences that one has upon the other. That said, the role that a language has in any given society or culture is more to do with a question of the function that it plays in society and culture. To understand that role a functional view of language needs to be applied. Kachru breaks these functions down into depth and range:

$[\mathrm{T}]$ he term range refers to the contexts or domains in which [language] functions (law, education, business, and popular culture), and depth refers to the extent of use of [language] in the various levels of society. (Kachru \& Nelson, 2001: 15)

In many cultures and societies it is seen that use of the indigenous tongue has a wide range of functions and considerable depth and is connected to the maintenance of society while the role of EIL carries fewer functions and a limited degree of depth while being linked to its development. In the next section I will explore this further while examining the specific roles that EIL plays in both the development and maintenance of South Korean society.

\section{EIL in the Maintenance and Development of South Korean Society}

As seen above (section 5), language, society and culture are linked and each plays an influential role on the other. This is clear in the context of South Korea where both Hangul and English have distinct roles in the maintenance and development of culture and society. By looking at the function of each language it becomes easier to identify these roles. In regards to EIL, its function is that of a global language "providing access to the world community" (Crystal, 2001: 22) while Hangul "is a well-resourced regional language, providing access to a local community" (Crystal, 2001: 22). The two languages can be seen as working in tandem to respond to different needs: EIL functions on an international level, as a voice in global affairs, attracting international business and giving access to a wealth of academic knowledge where as Hangul, on the other hand, is an expression of local identity.

\subsection{Maintenance}

What is the role of EIL in the development and maintenance of South Korean society? South Korea spends considerable sums of money on English education. The size of the English education market in South Korea according to a recent report estimated that the "amount spent on 'English education' in 2005 reached up to 15 trillion won (nearly $\$ 15$ billion), including the money spent for tests of English" (H-C. Chun \& H-S. Choi, 2006 cited in Park, Jin-Kyu 2009: 51). That said, many have no use for the language in their daily lives and, as is the case in Hong-Kong, "white-collar workers expend a lot of energy on English learning, despite having few opportunities to use it"(Lai, 1999 cited in Qiang \& Wolff, 2005: 56). In South Korea, this is because Hangul is the functioning language; it maintains Korean society and reflects its culture. For students studying English, EIL plays very little importance in their lives beyond the purposes of the classroom since "South Korea basically is a monolingual nation, where the majority of her population use Korean and no other languages in their everyday communication" (Song, 2011: 35). EIL is not needed, or appropriate, for communicative purposes within South Korean society. 


\section{Macrothink Institute ${ }^{\text {tm }}$}

Given that there is no communicative need of English inside South Korean society and that the language fails to fulfill the language requirements of its culture, what then is its role? The role of English is linked to the development of South Korean society and culture, which in turn is linked in some regard to its maintenance as a society that does not develop risks the possibility of stagnation. Therefore, it is considered that EIL does play a role in the maintenance of South Korean society, albeit, an indirect one.

\subsection{Development}

At the developmental level, EIL plays a functional role as a means for "specific purposes, for [international] business negotiations, collaborative research, academic discussions, and not for everyday life nor for socializing events" (Yano 2003: 80). At the business level, English is recognized as an important tool for international communication. Economic growth and prosperity in South Korea are strongly linked to foreign markets and the need to do business in international settings and the language skills necessary to do that puts EIL in a very favorable functional position. The figures below show that business with other expanding circle countries "have become increasingly important in [South] Korean foreign trade" (Chang, unpublished: 3) and in 2007 accounted for over $70 \%$ of its exports and nearly $80 \%$ of its imports (Imports and Exports in Korea: KOISIS cited in Chang: unpublished). This indicates that in business contexts, " [South] Koreans use English to communicate with other people whose mother tongue is not English" (Chang, unpublished: 3). EIL therefore plays a functional role and is linked to the development of South Korea's economy in an increasingly globalized world.

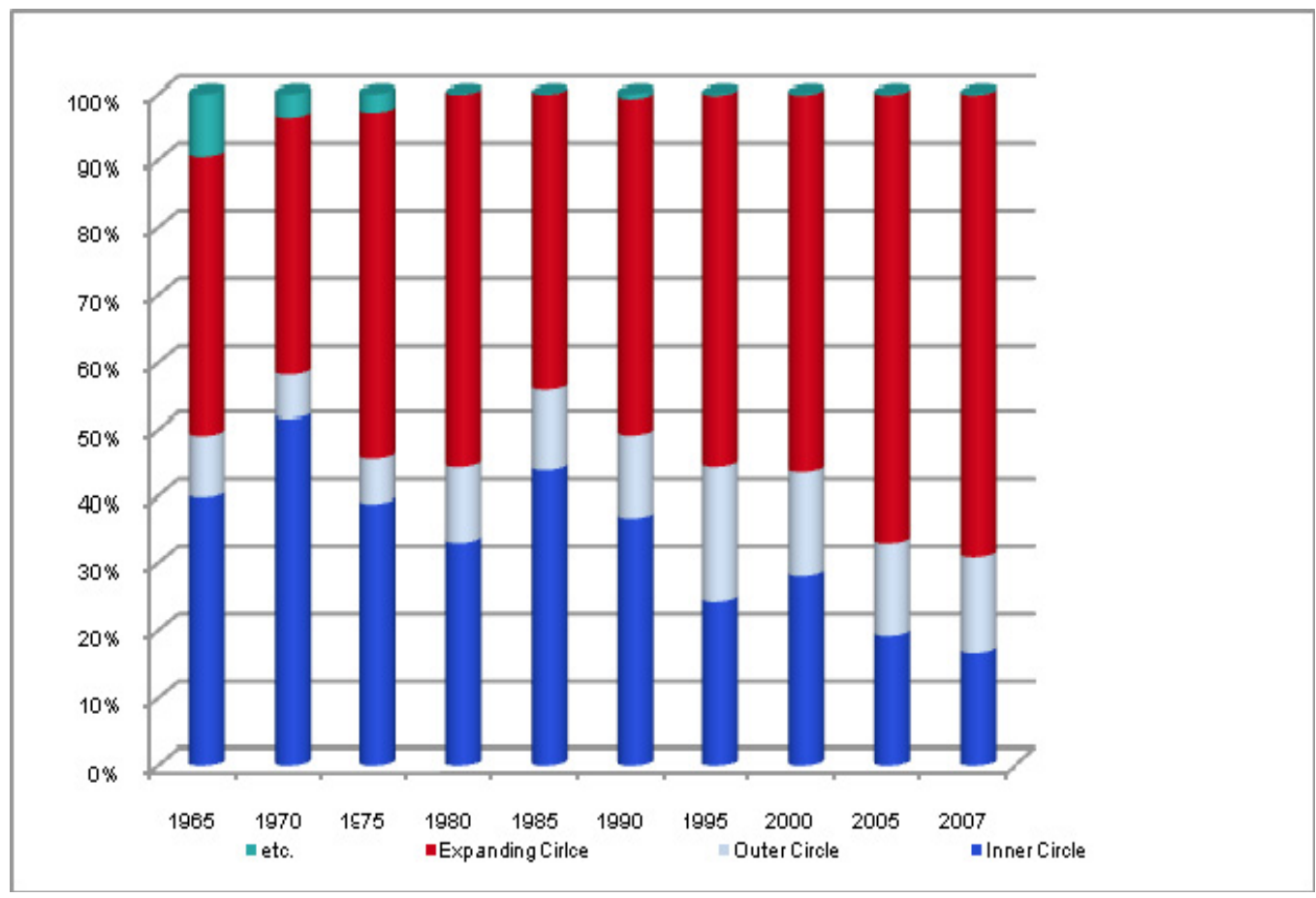

Figure 1. Value of Korean Exports by Country of Destination 1965 to 2007 (KOSIS) 


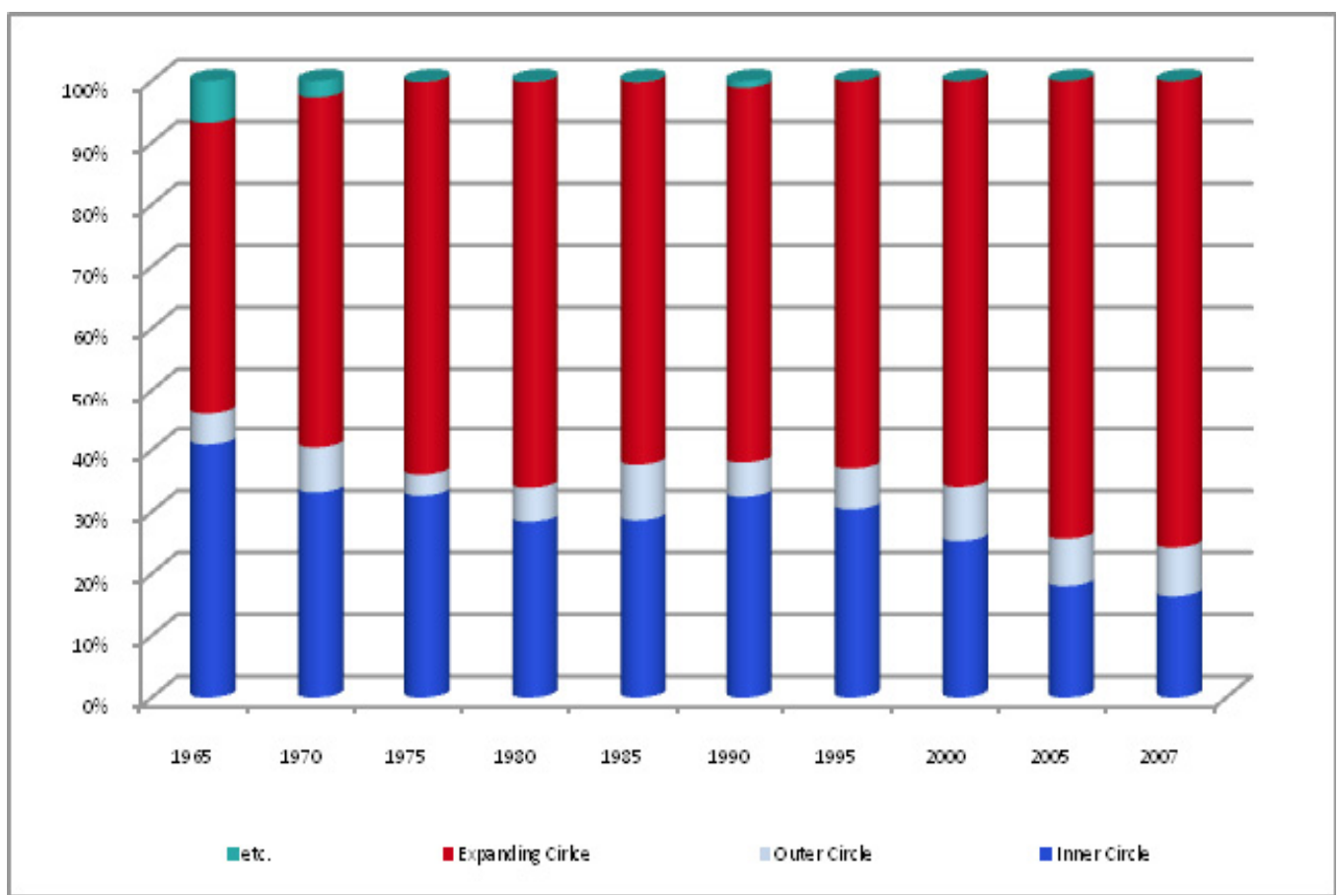

Figure 2. Value of Korean Import by Country of Origin from 1965 to 2007(KOSIS)

The above figures, based on (Chang, unpublished: 3) suggest that for international business purposes there exists a considerable range and depth for English in South Korea. It serves an EIL function for communication to other expanding circle countries and supports the observation that "a vast majority of Asians... do not learn it with the intention to communicate with native speakers but to communicate with other non-native speakers (Kirpatrick, 2004; cited in Patil, 2006: 117).

Academically, English assumes another functional role as the key to unlocking a wealth of knowledge, especially in the fields of science and technology. Through English, students are able to access knowledge that may otherwise be unavailable to them. This knowledge is used for innovative solutions that are beneficial to the development of society.

What is evident is that in South Korea English is being used for pragmatic reasons, and these reasons are beneficial to the development of society in an increasingly globalized environment. EIL is not a language that is being used internally for communicative purposes. Rather, it is an additional linguistic skill being learnt for the purposes of international business communication and academic advancement both contributing to South Korea's rising presence in the international arena. 


\section{EIL in South Korea: Neutral, Imperialist or Democratic?}

Having discussed the functional and pragmatic role for EIL in South Korean society and culture, let us now look at whether or not it can be considered as neutral, imperialistic or democratic.

\subsection{Neutral}

The author believes that EIL in South Korea cannot be considered neutral (see section 4.1) because "each language encapsulates the world-view of its speakers" (Wardhaugh, 2006: 379) and it is "the imposition of new 'mental structures' through English" (Phillipson, 1992: 166) that translates into an understanding that even though English is being learnt in South Korea for specific purposes linked with the development of South Korean society in a way that does not threaten Hangul, the effect is still one that adds to an existing linguistic resource and this alters and changes perceptions. Wardhaugh further states that:

[W]e are thus introduced to a new principle of relativity, which holds that all observers are not led by the same physical evidence to the same picture of the universe, unless their linguistic backgrounds are similar, or can in some way be calibrated. (2006: 223)

Here in South Korea words and meanings now exist that did not before the acquisition of English. An increase in a persons linguistic capabilities means that no language can ever be considered neutral. In addition, the use of English in South Korean culture is seen throughout society, from K-pop songs, business English signs to domestically manufactured products in the store. So while English is no longer dominated by the culture of inner-circle countries it still cannot be considered neutral as it is having an effect upon South Korean society.

A further argument against the neutrality of English in South Korea is the integration of English loan words into the Hangul language. Although these loan words have been adapted to the Korean phonological system in South Korea, in the North they have been substituted through translation to Hangul words. The table below, which is based on (Lee et al, 2010: 350) shows the difference of South and North Korean incorporation of English loan words. That there exists such internalization of English in South Korean everyday language use is further support to the argument that the role of English in South Korea cannot be considered neutral. 


\section{Macrothink}

Table 1. Integration of English loan words into the Hangul language

\begin{tabular}{|c|c|c|}
\hline English word & South Korean word & North Korean word \\
\hline Accessory & 액 세 서 리[aeksesori] (accessory) & 치 레 걸 이 [ch'irekori] (adornment hanger) \\
\hline Balcony & 발 코 니 [balk'oni] (balcony) & 내 민 대 [naemindae] (stick-out stander) \\
\hline Bell & 벨 [bel] (bell) & 전 기 종 [chon'gijong] (electric gong) \\
\hline Bulldozer & 불도 저 [buldojo] (bulldozer) & 평 토 기[p'yongt'ogi] (land plain-er) \\
\hline Curtain & 커 튼 [k'otun] (curtain) & 창 문 보 [ch'angmunbo] (window cloth) \\
\hline Diving & 다 이 빙 [daibing] (diving) & 뛰 여 들 기 [ttwuiodulgi] (jumping in) \\
\hline Dribble & 드 리 블 [dribul] (dribble) & 두 번 몰 기[tubonmolgi] (double driving) \\
\hline $\begin{array}{l}\text { Dry } \\
\text { cleaning }\end{array}$ & $\begin{array}{l}\text { 드 라 이 클 리 닝[duraik'ulining] } \\
\text { (dry cleaning) }\end{array}$ & $\begin{array}{l}\text { 화 학 세 탁 [hwahaksetak] } \\
\text { (chemical laundry) }\end{array}$ \\
\hline Fuse & 퓨 즈 [p'yuju] (fuse) & 녹 는 쇠 [noknunsoe] (melting iron) \\
\hline Helicopter & $\begin{array}{l}\text { 헬 리 콥 터[haelikopt'o] } \\
\text { (helicopter) }\end{array}$ & 직 승 기 [chiksung'gi] (straight-up plane) \\
\hline Ice cream & $\begin{array}{l}\text { 아 이 스 크 림 [aisuk'urim] } \\
\text { (ice cream) }\end{array}$ & 얼 음 보숭 이 [orumposung'i] (icy cluster) \\
\hline Knock & 노 크 [nok'u] (knock) & 손 기 척 [songichok] (hand indication) \\
\hline K.O. & 케 이 오 [k'ae'i'o] (K.O.) & $\begin{array}{l}\text { 완 전 넘어 지 기 [wanjonnomojigi] } \\
\text { (complete fall down) }\end{array}$ \\
\hline Mammoth & 암 모스[mam'mosu] (mammoth) & 털 코끼리 [t'olkokkiri] (hairy elephant) \\
\hline Mannequin & 마 네 킨 [manek'in] (mannequin) & 몸 틀 [momt'ul] (body frame) \\
\hline Mask & 마스 크 [masuk'u] (mask) & 얼 굴 가 리 개 [olgulkarige] (face cover) \\
\hline Mosaic & 모 자 이 크 [mojaik'u] (mosaic) & $\begin{array}{l}\text { 쪽 무 니 글 림 [tchokmunikurim] } \\
\text { (piece figured painting) }\end{array}$ \\
\hline Musical & 유 지 컬 [myujik‘ol] (musical) & $\begin{array}{l}\text { 가 우 이 야 기 [kamuiyagi] (singing and } \\
\text { dancing story) }\end{array}$ \\
\hline Perm & 파 마 [p'ama] (perm) & 볶음 머 리[pokkum'mori] (roasted hair) \\
\hline Pin & 핀 [p'in] (pin) & 못 [mot] (nail) \\
\hline Rotary & 로 터 리 [rot'ori] (rotary) & $\begin{array}{l}\text { 도 는 네 거 리 [tonun'nekori] (circling } \\
\text { crossroads) }\end{array}$ \\
\hline Spray & 스 프 레 이 [sup'urei] (spray) & 솔 솔 이[solsori] (soft blower) \\
\hline Stocking & 스 타 킹 [sut'aking] (stocking) & $\begin{array}{l}\text { 훈 동 긴 양 말 [undong'gin'yangmal] } \\
\text { (sports-long-socks) }\end{array}$ \\
\hline Switch & 스 위 치 [suwich'i] (switch) & 여 닫 게 [yotat'ge] (opener-closer) \\
\hline Trailer & 트 레 일 러[t'ureillo] (trailer) & 연 결 차 [yon'gyolch'a] (linking car) \\
\hline
\end{tabular}

\subsection{Imperialist}

The main thread to the argument that English is imperialist is that it is imposed and successfully displaces indigenous languages (Judd, 1983; Day, 1985; Cook, 1988; Phillipson 1992; Muhlhausler 1996). Is EIL in South Korea imperialist? I don't believe it is. In South Korea, English is a bilingual choice and one that is undertaken knowing full well that the mother tongue (Hangul) is not in anyway threatened.

While supporters of the imperialist role argue that because it is a compulsory subject this equates to an imperialistic imposition of the language upon its learners, they fail to recognize the realism of the situation. While it is true that English is a compulsory subject in South Korea, Jo points out that:

"Elementary school English is only an hour or 2-hour lesson a week, a total of only 34-68 hours a year. The lessons in middle and high school consume 3-5 hours a week [or] 102-170 a year. (2008: 375) 
This is clearly not enough to supplant the mother tongue. These sentiments are shared by Bisong who states:

There is no way three or four hours of exposure to English in a formal school situation could possibly compete with, let alone threaten to supplant, the non-stop process of acquiring competence in the mother tongue. (1995: 125)

Although English has had some influence in the language used in South Korean society domestically, it plays a role that has limited range and has therefore not attained a large degree of depth. Here in South Korea, the use of English is a choice that is made for pragmatic reasons and is used as a language for specific purposes from expressing South Korean culture to the world, accessing a wealth of knowledge to securing international business connections. That it is used for international rather than intra-national purposes and alongside Hangul, which is the functioning language of South Korean society, it is in no way threatening nor does it appear be playing an imperialist role here in South Korea.

\subsection{Democratic}

EIL in South Korea is neither neutral nor imperialist, but is it democratic? I don't believe that it is. Whilst it does serve a functional role in giving access to knowledge and opening up opportunities that did not exist before for travel and employment it also actively maintains a class system. For example, access to prestigious universities is based on English fluency tests in addition to which, English is considered a necessary condition for employment and promotion. It is a "continuation of the reward system that gives a great advantage to those with 'good education' over those without”(Song, 2011: 47).

That considerable inequity seems to exists in terms of access to effective English language instruction, with some parents spending "one million won (nearly \$1,000) a month to English-immersion schools where their 5- to 6-year-old children learn English from native speakers of English" (Park 2009: 51), it is clear that although English "remains a gatekeeper to higher education, better jobs and social position" (Lai, 1999; cited in Qiang \& Wolff 2005: 56) that access to these benefits are more accessible to the elite classes.

It is evident that the role of English in South Korea should not be seen as neutral, imperialist or democratic, but rather as functional and pragmatic. These days, "English plays an important role in the fields of politics, economics, trade, commerce, sightseeing, study abroad and other activities" (Jo, 2008: 380) and is spoken for EIL purposes. Throughout this paper it has been determined that the role English plays in South Korea is functional and pragmatic. Acquisition of EFL in South Korea is for EIL purposes, implying that the function it plays is to facilitate communication in international contexts between other non-native as well as native speakers of English, but increasingly between members from outside the inner-circle. This has implications for teaching English in South Korea and will be discussed in the following section.

\section{Implications for Teaching English in South Korea}

Given that "the ratio of native to non-native is around 1:3" (Crystal 2003: 69) and that the 
purposes of EIL are now increasingly to facilitate communication between non-native speakers, it seems somewhat outdated to believe "that someone who wants to learn English as a second or a foreign language does so in order to be able to communicate with the so-called native speakers of English"(Rajagopalan, 2004:114).

This has implications for the teaching of English in South Korea as, "more and more people across the globe will be using the language for communication between non-English speakers than for linguistic encounters involving at least one native speaker" (Rajagopalan, 2004:115). Teaching should therefore be less about "learning ...the concerns and cultures of what Kachru (1985) terms Inner Circle countries" (McKay, 2003: 2). This implies that there is a need to prepare students in South Korea to speak with other non-native speakers and equip them for the more responsible global need for the language.

The implications are that EFL teachers need to expose their students "to as many varieties of English as possible, especially those which they are most likely to encounter in their own locale" (Crystal, 2001: 60). In order to do that that there is a need to focus on World English by bringing it into our language classrooms and showing that even though "there are differences [this] does not automatically imply that someone is wrong" (Krachu and Nelson, 2001: 12). In addition, there is a call to center on interpretability to better prepare students for the types of English they need to use in the future.

Furthermore, there is a necessity to recognize that "teaching methods and materials, and educational policies, need to be adapted for local contexts" (Graddol, 2001: 36) as "the educational goal of learning an international language is to enable learners to communicate their ideas and culture to others" (McKay 2003: 3) and not regurgitate the cultures of the inner circle countries. As McKay (2002: 129) rightly points out, "the concept of thinking globally but acting locally is highly relevant to the teaching of EIL". To adopt these practices will also ensure that EFL professionals will help to make English more democratic because there would be less of a focus on the West in terms of standards and culture.

\section{Conclusions}

In conclusion, I do not believe EIL is neutral in South Korea though I do think that it is significantly divorced from any specific culture. Likewise, EIL does not play a democratic or imperialist role in South Korea, as it still serves to maintain existing class structures but is also a language choice that does not threaten the Hangul mother tongue. Instead, I subscribe to the notion that EIL is functional and that its role is to do with the development of South Korean society and that this development is tied to its maintenance. The function that it performs alongside the native tongue brings many visible benefits to its society.

Furthermore, what is clear is that EFL is being used for EIL purposes to facilitate communication between non-native speakers. This implies there is a need to focus on interpretability to prepare students for the vast range of linguistic diversity that they are likely to encounter outside the EFL classroom. It is with this in mind that EFL teachers should approach their classroom pedagogy. 


\section{Acknowledgement}

This work was supported by Hankuk University of Foreign Studies Research Fund 2015.

\section{References}

Bickley, V. (1982). 'The International Uses of English: Research in Progress'. In English for International Communication, edited by Christopher Brumfit. Oxford: Pergamon Press.

Bisong, J. (1995). 'Language choice and cultural imperialism: a Nigerian perspective'. ELT journal 49.2: 122-132. http://dx.doi.org/10.1093/elt/49.2.122

Bolton, K. (2004). 'World Englishes'. In A. Davies \& C. Elder (Eds.), The Handbook of Applied Linguistics (pp. 369-396). Oxford, England: Blackwell. http://dx.doi.org/10.1002/9780470757000.ch15

Burns, A., \& Coffin, C. (2001). Analysing English in a Global Context. Routledge

Chang, K-S. (Unpublished) 'Status and Function of English as a Language of International/Intercultural Communication in Korea - Accessed online Nov 252012 http://www.oecd.org/edu/ceri/41506521.pdf

Chun, H-C. \& Choi, H-S. (2006). 'Economics of English.' CEO Information, No. 578. Samsung Economic Research Institute.

Cooke, D. (1988). 'Ties that constrict: English as a Trojan horse'. In A. Cumming, A. Gagne, \& J. Dawson (Eds.), Awarenesses: Proceedings of the 1987 TESL Ontario Conference (pp. 56-62). Toronto: TESL Ontario.

Crystal, D. (2001). 'The Future of Englishes'. In Burns, Anne, and Caroline Coffin Analysing English in a Global Context: Routledge.

Crystal D. (2003) English as a Global Language. Cambridge University Press. http://dx.doi.org/10.1017/CBO9780511486999

Day, R, D. (1985). 'The Ultimate Inequality: Linguistic Genocide' in Wolfson, Nessa, and Joan Manes. Language of inequality. Vol. 36. Walter de Gruyter, 1985.

Graddol, D. (1997). 'The future of English'. British Council 1997.

Graddol, D. (2001). 'English in the future'. In Burns, Anne, and Caroline Coffin Analysing English in a Global Context. Routledge.

Holland, R. (2002). 'Globospeak? Questioning Text on the Role of English as a Global Language' Language and Intercultural Communication 2:1, 5-24. http://dx.doi.org/10.1080/14708470208668072

Jo, S. (2008). "English education and teacher education in South Korea." Journal of Education for Teaching 34.4 : 371-381. http://dx.doi.org/10.1080/02607470802401594

Judd, E. I. (1983). 'TESOL as political act: A moral question'. In J. Handscombe, R.A. Orem, and B.P. Taylor (Eds.), On TESOL 83 (pp. 265-73). Washington, DC: TESOL. 
Kachru, B. and Nelson, C. (2001). 'World Englishes'. In Burns, Anne, and Caroline Coffin. Analysing English in a global context. Routledge.

Kachru, B. (1982). The Other Tongue -- English Across Cultures. Urbana, Ill.: University of Illinois Press.

Kachru, B. (1986). The alchemy of English: The Spread, Functions and Models of Non-native Englishes: Oxford, England: Pergamon Press.

Kachru, B. (1992). 'Teaching World Englishes'. In B. B. Kachru (Ed.), The other tongue. English across cultures (2nd ed., pp. 355-365). Urbana, IL: University of Illinois Press.

Lai, M, L. (1999). 'Hong Kong: Language and education in a Post-colonial Era.' In Language, Culture and Curriculum 12:3. http://dx.doi.org/10.1080/07908319908666577

Lee, J-H, Min W-H, and McKerrow R, E. 'English or perish: how contemporary South Korea received, accommodated, and internalized English and American modernity." Language and $\begin{array}{llll}\text { Intercultural } & \text { Communication } & 10.4 & \text { (2010): }\end{array}$ http://dx.doi.org/10.1080/14708477.2010.497555

McCrum, R. (2010). Globish. How the English Language became the World's Language London: Penguin Viking.

McKay, S. L. (2003). 'Toward an appropriate EIL pedagogy: re-examining common ELT assumptions'. International Journal of Applied Linguistics Vol13 No1. http://dx.doi.org/10.1111/1473-4192.00035

McKay, S. L. (2003). 'Toward an appropriate EIL pedagogy: Re - examining common ELT assumptions'. International Journal of Applied Linguistics 13.1: 1-22. http://dx.doi.org/10.1111/1473-4192.00035

McKay, S. L. (2002). Teaching English as an international language: Rethinking goals and approaches. Oxford University Press, USA.

Mühlhäusler P. (1996). 'Atlas of Languages of Intercultural Communication in the Pacific, Asia, and the Americas'. Texts. Vol. 2. Mouton de Gruyter.

Park, J-K. (2009). 'English fever' in South Korea: its history and symptoms. English Today Volume 25 Issue 1.

Patil, Z.N. (2006). 'On the Nature and Role of English in Asia'. The Linguistic Journal Vol1, Number 2.

Pennycook, A. (1998). English and the discourses of colonialism. Routledge, 1998.

Pennycook, A. (2001). 'English in the world/The world in English'. In Burns, Anne, and Caroline Coffin. Analysing English in a global context. Routledge.

Phillipson, R. and Skutnabb-Kangas, T. (1996). 'English Only Worldwide or Language Ecology?’ TESOL Quarterly, Vol. 30, No. 3. http://dx.doi.org/10.2307/3587692 
Phillipson, R. (1992). Linguistic Imperialism. Oxford University Press.

Qiang, N. and Wolff, M. (2005). 'Is EFL a modern Trojan horse?'.English Today 84: 55. http://dx.doi.org/10.1017/S0266078405004128

Rajagopalan, K. (2004). 'The concept of 'World English'and its implications for ELT'. ELT Journal 58.2: 111-117. http://dx.doi.org/10.1093/elt/58.2.111

Sasaki, M. Suzuki, T. and Yoneda, M. (2006). 'English as an International Language in Non-Native Settings in an Era of Globalization'. Comparative Sociology, Volume 5, issue 4.

Sharifian, F. (2009). 'English as an International Language: An overview'. In English as an International Language. Multilingual Matters Bristol Buffalo Toronto.

Song, J-J. (2011). 'English as an official language in South Korea: Global English or social malady?'. Language Problems \& Language Planning 35.1: 35-55. http://dx.doi.org/10.1075/lplp.35.1.03son

Smith, L. (1976). 'English as an International Auxiliary Language.” RELC Journal 7(2): 38-43. http://dx.doi.org/10.1177/003368827600700205

Wardhaugh, R. (2006). An Introduction to Sociolinguistics. Blackwell Publishing.

Widdowson, H, G. (1998). 'EIL: Squaring the circles. A reply.' World Englishes, Vol 17, No.3 397-401. http://dx.doi.org/10.1111/1467-971X.00113

Yano, Y. (2003). 'Communicative Competence and English as an International Language'. Intercultural Communication Studies XII-3.

\section{Copyright Disclaimer}

Copyright for this article is retained by the author(s), with first publication rights granted to the journal.

This is an open-access article distributed under the terms and conditions of the Creative Commons Attribution license (http://creativecommons.org/licenses/by/3.0/). 